\title{
Model of metabolic and temperature fluctuations in the brain
}

\author{
Jan Karbowski \\ From Twentieth Annual Computational Neuroscience Meeting: CNS*2011 \\ Stockholm, Sweden. 23-28 July 2011
}

\begin{abstract}
A general theory of metabolic, hemodynamic, and thermodynamic fluctuations in the cerebral cortex is presented based on mesoscopic activities of neurons and synapses. Spectral functions of fluctuations in metabolic activity, cerebral blood flow, and tissue temperature are determined analytically and discussed with respect to underlying fluctuations in neural activity. The dependence of these fluctuations on general neuroanatomical organization is also discussed. It is found that spatial temperature correlations have a long-range character due to heat diffusion, even in the absence of such correlations in neural activities. Based on these results, it is suggested that experimental imaging of brain temperature distribution may be useful in determining local activities of neurons. The paper is an extension of the previous approach [1], where metabolic power of cortical neurons was determined analytically.
\end{abstract}

\section{Acknowledgments \\ The paper was supported by the grant from the Polish Ministry of Higher Education (NN 518 409238), and by the Marie Curie Actions EU grant FP7-} PEOPLE-2007-IRG-210538.

Published: 18 July 2011

\section{Reference}

1. Karbowski J: Thermodynamic constraints on neural dimensions, firing rates, brain temperature and size. J. Comput. Neurosci 2009, 27:415-436.

Submit your next manuscript to BioMed Central and take full advantage of:

- Convenient online submission

- Thorough peer review

- No space constraints or color figure charges

- Immediate publication on acceptance

- Inclusion in PubMed, CAS, Scopus and Google Scholar

- Research which is freely available for redistribution

Submit your manuscript at www.biomedcentral.com/submit
() Biomed Central 